\title{
SCG2 wt Allele
}

National Cancer Institute

\section{Source}

National Cancer Institute. SCG2 wt Allele. NCI Thesaurus. Code C52407.

Human SCG2 wild-type allele is located within 2q35-q36 and is approximately 5 kb in length. This allele, which encodes secretogranin-2 protein, is involved in the mediation of both neuronal hormone secretion and chemotaxis. 